Review

\title{
Nutritional Management of Insulin Resistance in Nonalcoholic Fatty Liver Disease (NAFLD)
}

\author{
Beth A. Conlon ${ }^{1, *}$, Jeannette M. Beasley ${ }^{1}$, Karin Aebersold ${ }^{1}$, Sunil S. Jhangiani ${ }^{2}$ and \\ Judith Wylie-Rosett ${ }^{1}$
}

1 Department of Epidemiology and Population Health, Albert Einstein College of Medicine, 1300 Morris Park Avenue, Bronx, NY 10461, USA;

E-Mails: jeannette.beasley@einstein.yu.edu (J.M.B.); karin.aebersold@einstein.yu.edu (K.A.); judith.wylie-rosett@einstein.yu.edu (J.W.-R.)

2 Division of Gastroenterology and Clinical Nutrition, Department of Internal Medicine, Montefiore Medical Center (Wakefield), 2425 Eastchester Road, Bronx, NY, 10469, USA; E-Mail: sjgimd@aol.com

* Author to whom correspondence should be addressed; E-Mail: beth.conlon@phd.einstein.yu.edu; Tel.: +1-718-430-4084; Fax: +1-718-430-8634.

Received: 18 May 2013; in revised form: 14 August 2013 / Accepted: 19 September 2013 / Published: 11 October 2013

\begin{abstract}
Nonalcoholic fatty liver disease (NAFLD) is an emerging global health concern. It is the most common form of chronic liver disease in Western countries, affecting both adults and children. NAFLD encompasses a broad spectrum of fatty liver disease, ranging from simple steatosis (NAFL) to nonalcoholic steatohepatitis (NASH), and is strongly associated with obesity, insulin resistance, and dyslipidemia. First-line therapy for NAFLD includes weight loss achieved through diet and physical activity. However, there is a lack of evidenced-based dietary recommendations. The American Diabetes Association's (ADA) recommendations that aim to reduce the risk of diabetes and cardiovascular disease may also be applicable to the NAFLD population. The objectives of this review are to: (1) provide an overview of NAFLD in the context of insulin resistance, and (2) provide a rationale for applying relevant aspects of the ADA recommendations to the nutritional management of NAFLD.
\end{abstract}

Keywords: nonalcoholic fatty liver disease; nonalcoholic steatohepatitis; hepatic steatosis; insulin resistance; diabetes; nutrition; macronutrients; review 


\section{Introduction}

Non-Alcoholic Fatty Liver Disease (NAFLD) is an increasing global health concern, with an estimated prevalence of $20 \%-30 \%$ in Western countries and $15 \%$ in Asian countries [1]. The spectrum of NAFLD ranges from simple steatosis (NAFL) to nonalcoholic steatohepatitis (NASH) and cirrhosis (Figure 1). Approximately 3\%-5\% of patients with hepatic steatosis develop NASH, which may progress to end-stage liver disease or hepatocellular carcinoma [2]. NASH is projected to surpass hepatitis $\mathrm{C}$ virus (HCV) as the leading indication for liver transplantation in the United States over the next 20 years [3].

NAFLD is tightly linked with obesity and is regarded as the hepatic manifestation of the metabolic syndrome. Prevalence of NAFLD among individuals with type 2 diabetes is estimated to be $65 \%-70 \%$, which is more than twice the prevalence among people without diabetes [4,5]. Furthermore, NAFLD may be an independent predictor of future risk of cardiovascular events in the diabetic population [6]. First-line therapy for NAFLD includes weight loss achieved through diet and physical activity [7], but there is a lack of evidence-based nutrition recommendations to guide dietary intervention. The American Diabetes Association (ADA) [8-10] provides evidence-based nutrition recommendations that aim to reduce the risk of diabetes and cardiovascular disease (CVD), with goals that include regulating blood glucose and insulin levels, and improving lipid and lipoprotein profiles. The ADA recommendations are potentially applicable to the NAFLD population, given the high comorbidity rates shared among hepatic steatosis, insulin resistance, and CVD. The objectives of this review are to: (1) Provide an overview of NAFLD in the context of insulin resistance, and (2) build upon this information to provide a rationale for applying relevant aspects of the ADA recommendations [8-10] to the nutritional management of NAFLD.

Figure 1. Nonalcoholic Fatty Liver Disease (NAFLD) is histologically categorized into Nonalcoholic Fatty Liver (NAFL) and Nonalcoholic Steatohepatitis (NASH) [1,7,11].

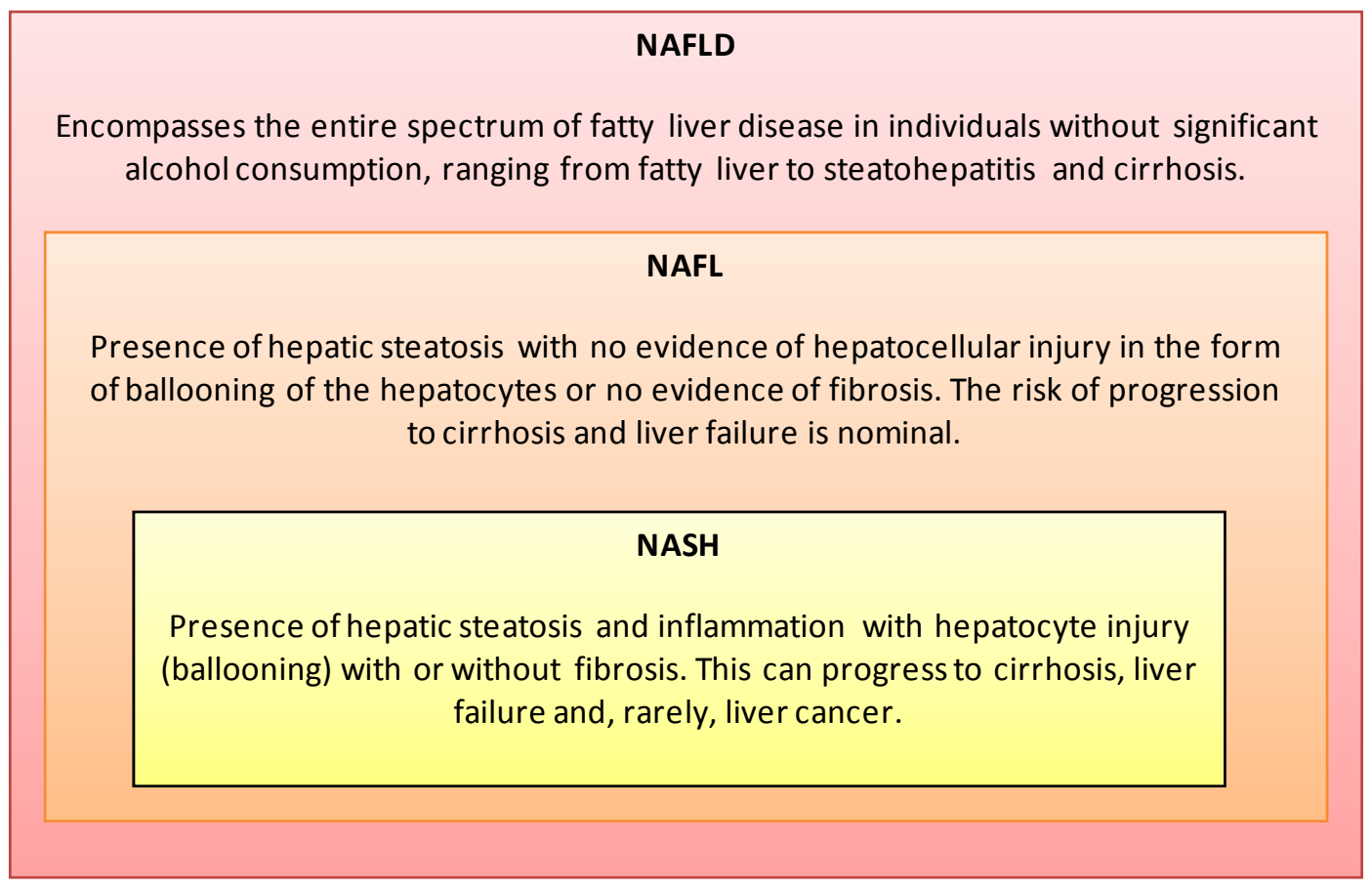




\section{Definition and Risk Factors}

In 2012, the American Association for the Study of Liver Diseases (AASLD), in collaboration with the American College of Gastroenterology and the American Gastroenterological Association, published the first evidence-based practice guidelines (AASLD Guidelines) for the diagnosis and management of NAFLD in both adults and children [7]. Prior to the AASLD Guideline, Ratziu and colleagues published a position statement summarizing the proceedings of the 2009 European Association for the Study of The Liver's (EASL) conference on NAFLD/NASH, and Sanyal and colleagues [12] summarized the consensus of a 2009 AASLD research workshop on endpoints and clinical trial design for NASH. The AASLD Guideline [7] definitions are provided in Figure 1.

According to the AASLD Guidelines [7], liver biopsy is the gold standard for the diagnosis of NAFLD, however imaging (e.g., ultrasonography) is more commonly used because of increased health risks and expenditures associated with liver biopsies. Criteria for diagnosis include hepatic steatosis by imaging or histology, exclusion of significant alcohol consumption ( $\geq 20 \mathrm{~g}$ alcohol/day in women and $\geq 30 \mathrm{~g}$ alcohol/day in men), and no existing hereditary disorders or competing etiologies for hepatic steatosis [7,12]. NAFLD is categorized as primary or secondary. Primary is associated with insulin resistance and metabolic derangements, and secondary is associated with non-insulin related conditions, as described elsewhere [13]. However, given that the prevalence of adult overweight and obesity exceeds $50 \%$ in many developed countries [14], it is not uncommon to observe primary NAFLD in the presence of other chronic liver diseases, such as alcoholic liver disease and chronic HCV [15].

The risk of advanced liver disease in NAFLD patients increases as the number of metabolic comorbidities increase [16]. Available data indicate that the prevalence of NAFLD likely exceeds $65 \%$ in type 2 diabetic populations and greater than $90 \%$ in morbidly obese populations [6,17]. NAFLD shares common risk factors with type 2 diabetes and other diseases influenced by lifestyle (Table 1), making lifestyle intervention a rational treatment for NAFLD. The prevalence of NASH is difficult to establish because a liver biopsy is required for diagnosis. More than $30 \%$ of morbidly obese patients may have NASH and 12\%-25\% have fibrosis [17-19]. Diabetes and insulin resistance may be more important predictors of NASH and fibrosis than BMI [20,21]. Moreover, due to the high prevalence of obesity among children [22], type 2 diabetes and related metabolic disorders are appearing in youth. An estimated $9.6 \%$ of the general pediatric population and $38 \%$ of the obese pediatric population in the United States are affected by NAFLD [23]. Pediatric NAFLD is likely to progress into adulthood, making prevention, early detection, and treatment an important issue across the lifecycle.

Table 1. Clinical and lifestyle risk factors associated with NAFLD [7,11].

\begin{aligned} \hline Clinical Risk Factors \\ \hline - \\ - Obesity \\ - Tysulin resistance ${ }^{\mathrm{a}} \\$ - Metabolic Syndrome $^{\mathrm{c}, \mathrm{d}}\left(\uparrow\right.$ central adiposity, dyslipidemia, hypertriglyceridemia, hypertension, $^{\mathrm{a}, \mathrm{a}} \\ \quad \uparrow$ fasting glucose $) \\$ - $\quad$ Cardiovascular disease \\ \hline\end{aligned}


Table 1. Cont.

- Endocrine (polycystic ovary syndrome, hypothyroidism, hypopituitarism, hypogonadism)

- Gallbladder disease

- Pancreato-duodenal resection

- Obstructive sleep apnea

- Starvation/malnutrition

\section{Lifestyle Risk Factors}

- Demographics ( $\uparrow$ age, first degree relatives of individuals with obesity or diabetes, sex ${ }^{\mathrm{e}}$, race $\left.^{\mathrm{f}}\right)$

- Western countries

- Western diet ( $\uparrow$ calories, $\uparrow$ saturated fat, $\uparrow$ trans fat, $\downarrow$ intake of $n-3$ fatty acids, vitamin $\mathrm{D}$, and fruits and vegetables)

- Physical inactivity

Abbreviations: $\uparrow=$ increase in; $\downarrow=$ indicates decrease in.

${ }^{a}$ Independent predictors of liver-related mortality in NAFLD [24]. ${ }^{\mathrm{b}}$ Type 1 diabetics have increased prevalence of NAFLD, based on liver imaging with limited histological evidence [25]. ${ }^{\mathrm{c}}$ Independent predictor of NASH risk [20]. ${ }^{\mathrm{d}}$ Metabolic syndrome lacks consistent definition [26,27]. AASLD Guidelines [7] cite Adult Treatment Panel III (ATP III) of the National Cholesterol Education Program [28]. ${ }^{\mathrm{e}}$ Men may have greater risk than women $[29,30] .{ }^{\mathrm{f}}$ Data from the U.S. indicate Hispanics and whites are at greater risk than blacks $[29,31]$.

\section{Pathophysiology}

NAFLD is a multifactorial disease with complex pathophysiology. Clinical hallmarks of NAFLD include obesity, insulin resistance, and dyslipidemia [32]. Adiposity is associated with a pro-inflammatory state, mediated by hormones and cytokines, such as tumor necrosis factor and interleukin-1. Hepatic lipid dysregulation, oxidative stress, and pro-inflammatory cytokines interact synergistically to promote hepatic fat accumulation over time [33]. Fatty infiltration of the liver results from an imbalance between hepatic lipid accumulation (from accelerated free fatty acid influx and de novo lipid synthesis) and hepatic lipid clearance (free fatty acid oxidation (FAO) and very low-density lipoprotein excretion). Accumulation of intracellular lipids is one proposed mechanism of insulin resistance, although whether insulin resistance is a cause or consequence of lipid accumulation remains debated. Day and colleagues [34] originally described this phenomenon in their "two-hit hypothesis" of the pathogenesis of NAFLD (Figure 2).

The first hit is metabolically driven, involving insulin resistance and lipid accumulation in hepatocytes [35]. Liver steatosis is associated with both hepatic and adipose tissue insulin resistance, as well as reduced systemic insulin sensitivity. Insulin resistance increases the rate of peripheral adipose tissue lipolysis, creating an increased flux of free fatty acids into the liver. Hyperinsulinemia and hyperglycemia promote lipid accumulation in hepatocytes by stimulating de novo lipogenesis while inhibiting FAO and lipid exportation in the liver, by mechanisms described elsewhere [32,36]. In the context of insulin resistance, a depletion of hepatic $n-3$ polyunstaurated fatty acids (PUFAs) has been reported [37]. $n-3$ PUFAs may play a critical role in regulating the metabolic switch from anabolism (lipogenesis) to catabolism (FAO) by activating peroxisome proliferator-activated receptor alpha (PPAR $\alpha$ ), a positive regulator of FAO $[38,39]$. The second hit occurs when lipid accumulation 
becomes toxic and induces a stress response in the liver, involving inflammation and oxidative stress. This can result in necrotic cell death, programmed (apoptotic) cell death, and lead to fibrosis and NASH.

Figure 2. The two-hit hypothesis of NAFLD progression [34]. Reproduced from [35] (Copyright (C) 2008 Novo et al.; licensee BioMed Central Ltd.).

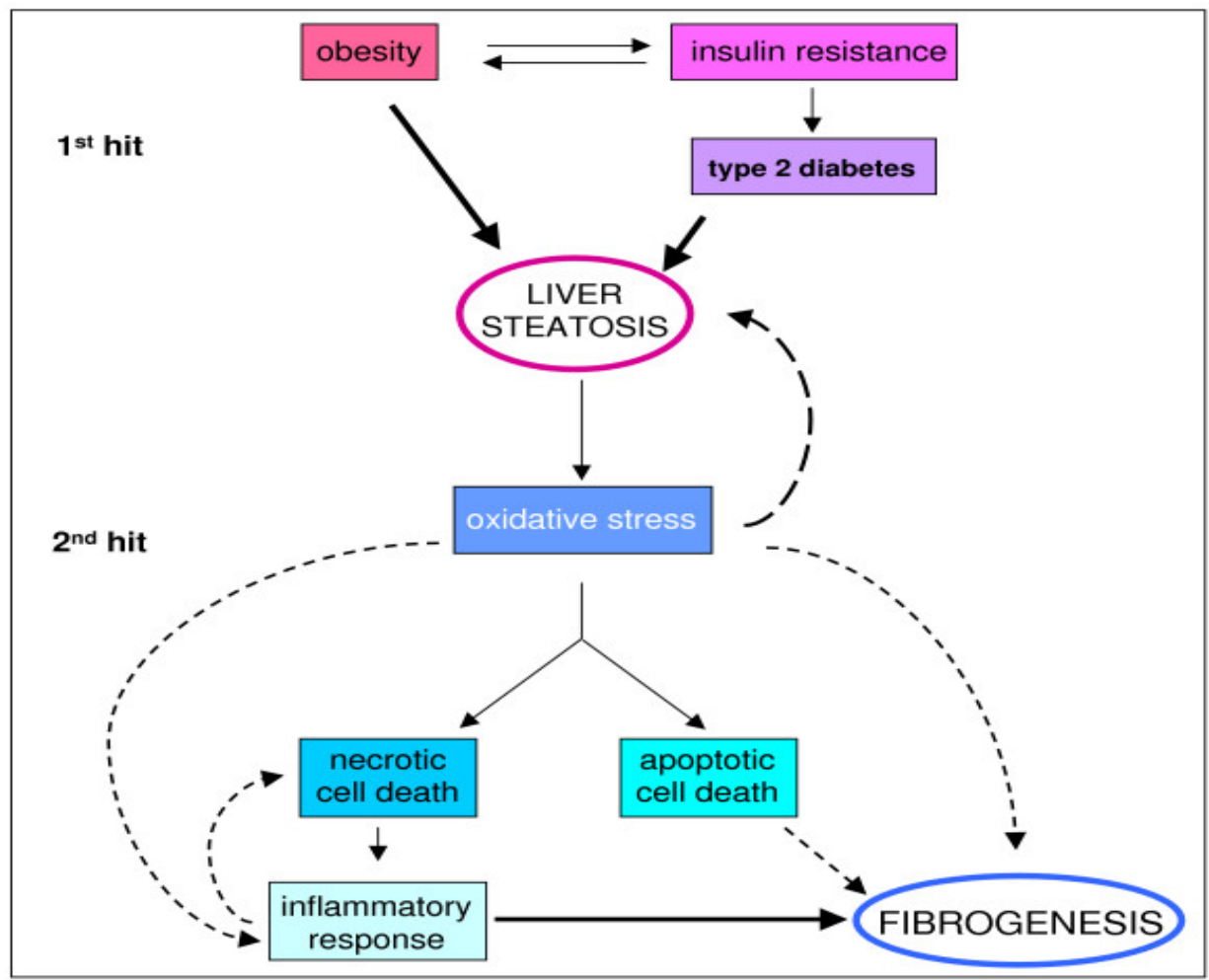

NASH occurs in a small subset of patients, which suggests that additional factors play a role. The pathogenesis of NASH is marked by increased inflammation, cytokines, and oxidative stress. A study of mice fed a high-fat diet for 8 or 12 weeks showed increased expression in the transcription factor, nuclear factor erythroid 2-related factor 2, a key regulator of redox homeostasis in cells, concomitantly with elevated liver index, alanine aminotransferase (ALT), cholesterol, and glucose [40]. Ibdah and colleagues [41] reported that aging mice with a heterozygous mutation for mitochondrial tri-functional protein, a critical enzyme in long-chain (13-21 carbon atoms) FAO, developed concomitant NAFLD and insulin resistance with higher levels of oxidative stress, as indicated by increased expression of cytochrome P-450 2E1 and decreased expression of glutathione. In a clinical study of adults $(n=82)$ with biopsy-proven NAFLD, altered secretion of obesity-related cytokines, such as adiponectin, leptin, and ghrelin were associated with more advanced NAFLD [42]. Antioxidant therapy for the treatment of NAFLD, including NASH, has the potential to ameliorate the oxidative stress and damage that promotes disease progression [43].

Collectively, these findings demonstrate the complex pathogenesis of NAFLD, and highlight areas for potential nutrition intervention. Weight loss decreases adipose tissue, thereby reducing both peripheral adipose tissue and hepatic insulin resistance (Figure 2). The AASLD Guidelines [7] recommend a weight loss of at least $3 \%-5 \%$ body weight to improve steatosis, and a weight loss of up to $10 \%$ may be needed to improve necroinflammation (Table 2). 
Intensive lifestyle intervention programs may be the most effective strategy for achieving these recommendations. Suzuki and colleagues $[44,45]$ reported that a 5\% weight reduction was sufficient for decreasing serum ALT, and the Look AHEAD trial [46] showed that a 12-month intensive lifestyle intervention program (average $8 \%$ weight loss) reduced steatosis, measured by proton magnetic resonance spectroscopy, and hemoglobin A1c (HbA1c) in overweight and obese adults with type 2 diabetes. The ADA recommends a 5\%-10\% [8-10] weight loss for the prevention and management of diabetes and CVD, consistent with the AASLD Guidelines [7] for NAFLD. However, the ADA recommendations [8-10] provide further guidance for medical nutrition therapy (MNT), with considerations given to macronutrients and micronutrients, including antioxidants and fatty acids [47]. MNT is an evidenced-based practice that delivers nutritional diagnosis, therapy, and counseling services for the purpose of disease management [48]. In the following section, we provide rationale for using the ADA recommendations [8-10] to guide dietary intervention in the NAFLD population and identify gaps for future research and clinical opportunities.

\section{Medical Nutrition Therapy}

A key difference between the ADA recommendations [8-10], AASLD Guidelines [7], and Dietary Guidelines for Americans (DGAs) [49] is that the DGAs are targeted to the general population rather than populations at high metabolic risk (Table 2). Similarly, existing obesity guidelines such as those established by the National Heart, Lung, and Blood Institute [50], emphasize delivery of patient care rather than individual management of metabolic risks. Thus, the ADA recommendations [8-10] are reasonable evidenced-based guidelines for the nutritional management of NAFLD and its associated comorbidities. Table 2 provides a summary of and comparison between the ADA recommendations [8-10], AASLD Guidelines [7], DGAs [49], and a proposed dietary framework from a recent review on the role of diet and nutrient composition in NAFLD by McCarthy and Rinella [47].

Table 2. Nutrition Guidelines and Recommendations for the General Population, Diabetes, and NAFLD.

\begin{tabular}{|c|c|c|c|c|}
\hline Organizations & USDHHS, USDA [49] & ADA $[8-10]$ & $\begin{array}{c}\text { AASLD, ACG, } \\
\text { AGA [7] }\end{array}$ & $\begin{array}{c}\text { McCarthy } \\
\text { and Rinella [47] }\end{array}$ \\
\hline $\begin{array}{l}\text { Document } \\
\text { Type }\end{array}$ & $\begin{array}{c}\text { Evidenced-based } \\
\text { Guidelines }\end{array}$ & $\begin{array}{c}\text { Evidenced-based } \\
\text { Guidelines }\end{array}$ & $\begin{array}{c}\text { Evidenced-based } \\
\text { Guidelines }\end{array}$ & $\begin{array}{c}\text { Professional } \\
\text { Review }\end{array}$ \\
\hline Population & $\begin{array}{l}\text { General U.S. } \\
\text { population. }\end{array}$ & Diabetes/Prediabetes & NAFLD/NASH & NAFLD/NASH \\
\hline Weight Loss & $\begin{array}{l}\text { Consume fewer } \\
\text { calories than } \\
\text { expended. This can be } \\
\text { achieved over time by } \\
\text { eating fewer calories, } \\
\text { being more physically } \\
\text { active, or, best of all, a } \\
\text { combination of } \\
\text { the two. }\end{array}$ & $\begin{array}{c}\text { Either } \\
\text { low-carbohydrate or } \\
\text { low-fat } \\
\text { calorie-restricted diets } \\
\text { may be effective } \\
\text { short-term } \\
\text { (up to one year). }\end{array}$ & $\begin{array}{c}3 \%-5 \% \text { of body weight } \\
\text { appears to improve } \\
\text { steatosis; up to } 10 \% \\
\text { weight loss may be } \\
\text { needed to improve } \\
\text { necroinflammation. May } \\
\text { be achieved either by } \\
\text { hypocaloric diet alone } \\
\text { or with increased } \\
\text { physical activity. }\end{array}$ & $\begin{array}{c}\text { Initial goal: } \\
5 \%-10 \% \text { body } \\
\text { weight lost over } \\
\text { one year. } \\
\text { Long-term goal: } \\
\text { ideal body weight, } \\
\text { maintenance of } \\
\text { weight loss. }\end{array}$ \\
\hline
\end{tabular}


Table 2. Cont.

\begin{tabular}{|c|c|c|c|c|}
\hline $\begin{array}{l}\text { Energy } \\
\text { (calories) }\end{array}$ & $\begin{array}{l}\text { Balance calories to } \\
\text { maintain weight. }\end{array}$ & $\begin{array}{l}\text { Hypocaloric diet for } \\
\text { weight loss based on } \\
\text { individual needs. }\end{array}$ & $\begin{array}{l}\text { Hypocaloric diet alone } \\
\text { or with physical activity } \\
\text { to promote weight loss. }\end{array}$ & $1200-1500 \mathrm{cal} /$ day. \\
\hline Carbohydrate & $\begin{array}{l}\text { Limit the consumption } \\
\text { of foods that contain } \\
\text { refined grains, } \\
\text { especially refined } \\
\text { grain foods that } \\
\text { contain solid fats, } \\
\text { added sugars, and } \\
\text { sodium. Reduce the } \\
\text { intake of calories from } \\
\text { added sugars. }\end{array}$ & $\begin{array}{l}\text { A dietary pattern that } \\
\text { includes carbohydrate } \\
\text { from fruits, vegetables, } \\
\text { whole grains, legumes, } \\
\text { and low-fat milk is } \\
\text { encouraged for good } \\
\text { health. Whole grains } \\
\text { should be one-half of } \\
\text { total grain intake. Fiber } \\
\text { intake same as general } \\
\text { population }(14 \mathrm{~g} \\
\text { fiber } 1000 \mathrm{kcal}) \text {. }\end{array}$ & Not specified. & $\begin{array}{l}\geq 50 \% \text { whole grain; } \\
\text { avoid high-fructose } \\
\text { corn syrup. }\end{array}$ \\
\hline Protein & $\begin{array}{c}10 \%-35 \% \text { total } \\
\text { calories. }\end{array}$ & $\begin{array}{l}\text { Insufficient evidence to } \\
\text { suggest that usual } \\
\text { protein intake } \\
(15 \%-20 \% \text { of energy) } \\
\text { should be modified. }\end{array}$ & Not specified. & $\begin{array}{l}\text { Lean animal- or } \\
\text { vegetable-based } \\
\text { protein. }\end{array}$ \\
\hline Total Fat & $\begin{array}{l}20 \%-35 \% \text { total } \\
\text { calories. }\end{array}$ & $\begin{array}{l}\text { Varies with diet; low-fat } \\
\text { or low-carbohydrate diet } \\
\text { for weight loss. }\end{array}$ & Not specified. & $\begin{array}{c}<35 \% \text { of total } \\
\text { calories. }\end{array}$ \\
\hline Saturated Fat & $<10 \%$ of total calories & $<7 \%$ of total calories. & Not specified. & $\begin{array}{c}<7 \% \text { of total } \\
\text { calories }\end{array}$ \\
\hline Trans Fat & $\begin{array}{c}\text { As minimal as } \\
\text { possible. }\end{array}$ & As minimal as possible. & Not specified. & $\begin{array}{l}\text { As minimal as } \\
\text { possible. }\end{array}$ \\
\hline $\begin{array}{l}\text { Unsaturated } \\
\text { Fatty Acids }\end{array}$ & $\begin{array}{l}\text { Replace saturated fats } \\
\text { with MUFA and } \\
\text { PUFA. }\end{array}$ & $\begin{array}{l}\text { Two or more servings of } \\
\text { fatty fish per week (with } \\
\text { the exception of } \\
\text { commercially fried } \\
\text { fish filets). }\end{array}$ & $\begin{array}{l}\text { Premature to } \\
\text { recommend; may be } \\
\text { considered as the first } \\
\text { line agents to treat } \\
\text { hypertriglyceridemia in } \\
\text { patients with NAFLD. }\end{array}$ & $\begin{array}{c}\text { Fish oil } 1 \text { gram/day } \\
\text { (eicosapentaenoic }+ \\
\text { docosahexaenoic } \\
\text { acids). Up to } 25 \% \\
\text { MUFA. }\end{array}$ \\
\hline Cholesterol & $<300 \mathrm{mg} /$ day. & $<200 \mathrm{mg} /$ day. & Not specified. & Not specified. \\
\hline Micronutrients & $\begin{array}{c}\text { Meet the } \\
\text { Recommended Dietary } \\
\text { Allowance or } \\
\text { Adequate Intake. }\end{array}$ & $\begin{array}{c}\text { No clear evidence of } \\
\text { benefit from vitamin or } \\
\text { mineral supplementation } \\
\text { in people with diabetes } \\
\text { (compared to the } \\
\text { general population) who } \\
\text { do not have underlying } \\
\text { deficiencies. }\end{array}$ & $\begin{array}{l}\text { Vitamin E } 800 \mathrm{IU} / \text { day in } \\
\text { non-diabetic adults with } \\
\text { biopsy-proven NASH. } \\
\text { Not recommended to } \\
\text { treat NASH in diabetic } \\
\text { patients, NASH } \\
\text { cirrhosis, or cryptogenic } \\
\text { cirrhosis. }\end{array}$ & $\begin{array}{l}\text { Vitamin E } \\
800 \text { IU/day. }\end{array}$ \\
\hline
\end{tabular}


Table 2. Cont.

\begin{tabular}{|c|c|c|c|c|}
\hline Sodium & $\begin{array}{c}<2300 \mathrm{mg} / \text { day general } \\
\text { population; } \\
<1500 \mathrm{mg} / \text { day if } \\
\geq 51 \text { years of age, } \\
\text { African American or } \\
\text { have hypertension, } \\
\text { diabetes, or chronic } \\
\text { kidney disease. }\end{array}$ & $\begin{array}{c}<2300 \mathrm{mg} / \text { day in } \\
\text { normotensive and } \\
\text { hypertensive } \\
\text { individuals; } \\
<2000 \mathrm{mg} / \text { day in } \\
\text { diabetics and patients } \\
\text { with symptomatic } \\
\text { heart failure. }\end{array}$ & Not specified. & Not specified. \\
\hline Alcohol & $\begin{array}{l}\text { If consumed, consume } \\
\text { in moderation (one } \\
\text { drink/day or less for } \\
\text { women and two } \\
\text { drinks/day or less } \\
\text { for men). }\end{array}$ & $\begin{array}{l}\text { If consumed, consume } \\
\text { in moderation (one } \\
\text { drink/day or less for } \\
\text { women and two } \\
\text { drinks/day or less } \\
\text { for men). }\end{array}$ & $\begin{array}{l}\text { Patients with NAFLD } \\
\text { should avoid heavy } \\
\text { amounts of alcohol } \\
\text { (3 drinks/day for } \\
\text { women, } 4 \text { drinks/day } \\
\text { for men). }\end{array}$ & Not specified. \\
\hline
\end{tabular}

Abbreviations: USDHHS = United States Department of Health and Human Services; USDA = United States Department of Agriculture; ADA = American Diabetes Association; AASLD = American Association for the Study of Liver Diseases; $\mathrm{ACG}=$ American College of Gastroenterology; AGA = American Gastroenterological Association; NAFLD = Nonalcoholic Fatty Liver Disease; NASH = Nonalcoholic Steatohepatitis; MUFA = monounsaturated fatty acid; mg = milligrams; $\mathrm{IU}=$ international units.

\subsection{Carbohydrates: Quantity and Quality}

The ADA does not recommend a single macronutrient distribution for all individuals with diabetes [8-10]. A dietary intake pattern that emphasizes whole grains, fruits, vegetables, legumes, and low-fat dairy is recommended for disease prevention and weight maintenance (Table 2). A hypocaloric, low-carbohydrate diet $(<40 \%$ carbohydrate) or low-fat diet $(<30 \%$ fat $)$ are recommended for weight loss. Low-carbohydrate diets may result in greater short-term ( $<6$ months) weight loss than a low-fat diet, but both diets have similar long-term ( $>1$ year) health benefits [51-54].

The quality or type of carbohydrate is likely to influence the development of NAFLD [47]. Excessive intake of simple or refined carbohydrates has been associated with obesity and insulin resistance in adults and children. A Western dietary pattern [55,56], which includes soft drinks, candies, and simple or refined carbohydrates, is a risk factor for NAFLD and is typical of a high glycemic index (GI) dietary pattern. The glycemic index is a quantitative measure of a food's carbohydrate content through its glycemic effects [57]. Low-GI foods elicit a low postprandial glucose response and their regular consumption has been associated with reduced risk of diabetes and CVD [58-60]. Valtueña et al. [61] demonstrated a positive relationship between higher quartiles of dietary GI with higher grades of hepatic steatosis in a population of 247 apparently healthy adults. Because dietary GI and total carbohydrate intake are distinct measurements, the ADA encourages clinicians and researchers to consider the use of the GI and glycemic load, as it may provide a modest additional benefit over that observed when total carbohydrate is considered alone (Table 2) [8]. The low-fat dietary pattern recommended by the ADA typically features a low GI dietary pattern.

However, when the percentage of dietary carbohydrate is changed, the amount of fat and protein invariably change. These variations in macronutrient distributions make it difficult to attribute the 
effects of dietary changes to a single macronutrient (carbohydrate, protein, or fat), and to apply a universal definition to "low-carbohydrate" and "high-carbohydrate" diets, making it difficult to compare studies [62]. With these limitations in mind [62], several studies that have examined the effects of low-carbohydrate or low-fat diets on NAFLD are highlighted.

In a cross-sectional analysis, Kang et al. [21] observed that patients with metabolic syndrome consumed significantly more dietary carbohydrates (51\% vs. $45 \%$ total energy) and less dietary fat (34\% vs. 40\% total energy) than patients without metabolic syndrome. Those with metabolic syndrome also had significantly higher homeostatic model assessment index, a quantitative measure of insulin resistance, and greater histological severity of NAFLD. Ryan et al. [63] randomized obese, insulin-resistant participants to receive a hypocaloric diet containing moderately low-carbohydrate (40\%-45\%) intake, or a hypocaloric diet containing moderate-carbohydrate $(60 \%)$ intake, for 16-weeks. The moderately-low carbohydrate diet group had significantly greater decreases in serum ALT and circulating insulin, indicating the low-carbohydrate diet may be more effective for short-term health improvements. The Fatty Liver Ancillary Study of the Look AHEAD (Action for Health in Diabetes) trial [46] observed individuals randomized to receive 1-year of treatment to an intensive lifestyle intervention (ILI) group (moderate caloric restriction, $<30 \%$ fat of total energy, increased physical activity, weight loss goal of $7 \%$ body weight) or diabetes support and education (DSE) control group. The ILI group experienced significant reductions in hepatic steatosis and $\mathrm{HbA1c}$, but not in AST or ALT. At 12-months, $26 \%$ of the DSE participants versus $3 \%$ of the ILI participants without NAFLD at baseline developed NAFLD. Haufe and colleagues [64] randomized 102 overweight and obese individuals to a 6-month dietary intervention consisting of either low-carbohydrate or low-fat hypocaloric diets, and observed improvements in intrahepatic lipid content in both groups that did not significantly differ. However, subjects with high baseline intrahepatic lipids (>5.56\%) lost approximately 7 -fold more intrahepatic lipid than those with lower baseline values. Collectively, these studies do not discern significant differences between low-carbohydrate and low-fat diets for periods of greater than 6-months, which is consistent with observations in diabetic populations, as summarized by ADA reports [8-10].

However, it is likely that a very low-fat diet high in simple sugars may stimulate de novo fatty acid synthesis in the liver, independent of BMI and insulin [65,66]. McCarthy and Rinella [47] reported that increased intake of high fructose corn syrup (HFCS) is likely attributed to an increased risk of NAFLD [67,68]. Adults and children with NAFLD may consume 2-3 times more HFCS than non-NAFLD patients [67], and the lipid metabolism of children with NAFLD may be more sensitive to the metabolic effects of HFCS than children without NAFLD [69]. Decreasing or avoiding consumption of HFCS may be important in the nutrition intervention for the NAFLD population, particularly in insulin resistant patients with poor glycemic control. Similarly, the ADA recommendations [8-10] encourage individuals to limit consumption of simple or refined carbohydrates, and increase consumption of complex carbohydrates, such as those found in whole grains, legumes, fruits, and vegetables (Table 2).

While there is no clear consensus on the ideal macronutrient distribution of carbohydrates, a low-fat/high-GI diet or reduced carbohydrate diet may facilitate short-term $(<1$ year $)$ weight loss. Future investigations are warranted, particularly in long-term ( $>1$ year) randomized clinical trials (RCTs) to evaluate the effects of varying carbohydrate distributions, and study designs that control for 
the potential effects of weight loss. It is important to note that restricting total carbohydrate to less than $130 \mathrm{~g} /$ day, is not recommended for individuals with diabetes [8].

\subsection{Total Fat and Fatty Acids}

A Western-style dietary pattern is a risk factor for NAFLD, and is typically characterized by a high intake of saturated fatty acids (SFAs) with low amounts of $n-3$ PUFAs (eicosapentaenoic acid 20:5 [EPA], and docosahexaenoic acid 22:6 [DHA]) and monounsaturated fatty acids (MUFAs) [70]. High amounts of SFAs and low amounts of $n$-3 PUFA consumption are associated with oxidative stress, decreased FAO, and depletion of PUFAs in the liver [70]. Similar to $n-3$ PUFAs, diets low in MUFAs are associated with decreased levels of PPAR $\alpha$ particularly in the context of insulin resistance [71]. Dietary patterns rich in $n$-3 PUFAs and MUFAs may play an important role in preventing and treating NAFLD, as well as improving lipid metabolism in insulin resistant individuals $[9,72]$.

Bozetto et al. [73] published the first randomized intervention study to evaluate the effects of dietary strategies with and without exercise on liver fat content, independent of weight loss. The study evaluated hepatic fat content by proton nuclear magnetic resonance spectroscopy in 37 men and 8 women (ages 35-70 years) before and after randomization to one of four intervention groups (Table 3). The dietary interventions were based on two dietary strategies recommended by the ADA: (1) a high-carbohydrate ( $>50 \%$ ), high fiber, and low GI diet, and (2) a reduced carbohydrate (40\%-45\%) diet enriched with MUFAs. The diets were isocaloric and participants maintained weight throughout the study duration.

Table 3. Summary of dietary intervention groups in study by Bozzetto et al. [73].

\begin{tabular}{ccccccc}
\hline Group & CHO\% & Fat\% & MUFA\% & Fiber/1000 kcal & GI & $\begin{array}{c}\text { Supervised } \\
\text { Exercise }\end{array}$ \\
\hline CHO/fiber & 52 & 30 & 16 & 28 & 60 & No \\
CHO/fiber + Exercise & 52 & 30 & 16 & 28 & 60 & Yes \\
MUFA & 40 & 42 & 28 & 10 & 95 & No \\
MUFA + Exercise & 40 & 42 & 28 & 10 & 95 & Yes \\
\hline
\end{tabular}

Abbreviations: $\mathrm{CHO}=$ carbohydrate; $\mathrm{MUFA}=$ monounsaturated fatty acid, as percentage of total; $\mathrm{kcal}=$ kilocalories; $\mathrm{GI}=$ glycemic index; Exercise $=$ supervised exercise, $45-\mathrm{min} 2 \times /$ week.

After 8 weeks of intervention, hepatic fat content significantly decreased in the MUFA (-29\%) and MUFA + exercise (-25\%) groups, compared to the $\mathrm{CHO} /$ fiber $(-4 \%)$ and $\mathrm{CHO} /$ fiber + exercise groups $(-6 \%)$. There were no significant effects for exercise training or diet-exercise interaction. The $\mathrm{CHO}$ /fiber and high-MUFA groups did not differ in SFAs (7\%), but varied in total fat and MUFAs. Westerbacka et al. [74] was the only other study to measure diet-induced changes in hepatic fat content in the absence of weight loss. In a group of 10, non-diabetic overweight women, a high-fat diet (56\% total energy) promoted increased hepatic steatosis and serum insulin resistance, in comparison to a low-fat diet (16\% total energy) [74]. However, the high-fat group consumed significantly more saturated fat, which likely confounded the association between the high-fat diet and hepatic steatosis.

The ADA Systematic Review [9] identified one RCT that compared saturated fatty acid (SFA) intake with MUFA intake while total fat remained the same, but did not find significant differences in 
postprandial glucose or insulin response $[9,75]$. This led to question whether decreasing SFA and/or increasing MUFA exerts beneficial effects on postprandial triglyceride levels. McCarthy and Rinella's review identified evidence to support negative effects of high $(>10 \%)$ and low $(<6 \%)$ dietary SFA consumption, and suggested that a range of SFA between $6 \%$ and $10 \%$ may be most beneficial to patients with NAFLD (Table 2), with an intake of MUFA up to $25 \%$, and increased intake of $n-3$ PUFAs. The ADA and DGAs (Table 2) similarly encourage increased consumption of MUFAs and $n-3$ PUFAs, and decreased consumption of SFAs and trans fatty acids. The AASLD Guidelines [7] acknowledge that unsaturated fatty acids may be beneficial for NAFLD patients with hypertriglyceridemia.

The Mediterranean-style diet is touted for its associations with improved cardiovascular health [76], and is low in carbohydrates with high amounts of MUFA, vegetables, fruits, legumes, olive oil/nuts (MUFA), and fish ( $n$-3 PUFAs), with moderate amounts of wine and minimal amounts of SFAs. There is not a standalone definition for the Mediterranean-style eating pattern, but rather it is typically reflective of geographical and cultural practices of inhabitants of the Mediterranean region. Perez-Guisado and Munos-Serrano [77] administered the Spanish Ketogenic Mediterranean Diet ( $\leq 30 \mathrm{~g}$ of carbohydrates/day from green vegetables and salad, at least $30 \mathrm{~mL}$ of olive oil, $200-400 \mathrm{~mL}$ of red wine, no protein or calorie restriction) to 14 obese men over a 12-week period [78], and observed significant improvements in body weight, low-density lipoprotein cholesterol, metabolic syndrome parameters, and degree of hepatic steatosis. These findings corroborated the results of a prior study that tested the efficacy and safety of the diet [77]. While diets low in carbohydrates and high in MUFAs are evidenced to improve outcomes in NAFLD patients, it is difficult to discern whether the effects are attributed to the high MUFA, reduced carbohydrate intake (with possible ketogenesis), or both. Future studies should consider a comparison group to help answer this question, such as a moderate- to high-carbohydrate enriched MUFA group.

Moreover, the contribution of wine and $n-3$ PUFAs to the perceived health benefits of low-carbohydrate, enriched MUFA dietary patterns should be considered. Data from the National Health and Nutrition Examination Survey indicated participants who consumed up to $10 \mathrm{~g}$ of wine per day $(n=945)$ were half $(\mathrm{OR}=0.51 ; 95 \%$ CI $0.33,0.79)$ as likely to meet the criteria for suspected NAFLD (defined by elevated liver function tests) [79]. The ADA Systematic Review [9] concluded that individual components of the Mediterranean-style diet, including wine and high MUFA/olive oil, may not have independent effects on glycemic control, but may independently benefit cardiovascular risk factors.

The effect of $n$-3 PUFA supplementation on improving insulin resistance remains equivocal; however, eating fatty fish rich in $n$-3 PUFAs at least twice a week remains a key strategy for diabetes management. $n-3$ PUFA supplements have been associated with increases in fasting plasma glucose, but they are also associated with reductions in HbA1c and CVD risk factors [9,80,81]. Several studies have demonstrated effectiveness of $n-3$ PUFAs in the treatment of NAFLD. DHA supplementation (250-500 mg/day) significantly improved liver steatosis and insulin sensitivity in an RCT in children ( $n=60)$ [82]. $n$-3 PUFA supplementation in adult NAFLD patients similarly demonstrated improvements in NAFLD, glycemic control, and lipid profiles at 6-months (2-6 g/day) [83,84] and 12-months ( $1 \mathrm{~g}$ /day) [85]. One-year of dietary supplementation with olive oil enriched with $n-3$ PUFA also showed significant improvements in liver enzymes and triglycerides, with reported increases in adiponectin levels [86]. In an evaluation of the efficacy of $n-3$ PUFAs as a hypolipidemic agent in 
NAFLD patients with hypertriglyceridemia, 6-months of $n-3$ PUFA (15 mL/day) supplementation resolved fatty liver in $35 \%$ of patients [87]. EPA has similarly been shown to improve NASH, likely due to its antioxidative and anti-inflammatory properties [88]. These studies demonstrate an important role of $n$-3 PUFAs in the amelioration and possible reversal of NAFLD. Clinical trials examining the efficacy and dose-response of $n$-3 PUFA treatment, as well as the role of $n$-3 PUFAs in prevention are needed.

Although limited, research on dietary fat and fatty acids in patients with NAFLD trends favorably towards a moderate to low-carbohydrate diet with increased MUFA and $n$-3 PUFAs. Available data in the NAFLD population appears consistent with the ADA recommendations [8-10] and American Heart Association's diet and lifestyle recommendations [72]. Future research to support the work of Bozetto et al. [73] and further investigate the effects of Mediterranean-style diets and n-3 PUFA consumption or supplementation on hepatic steatosis is needed.

\subsection{Protein}

The AASLD Guidelines [7] do not specifically address protein intake, and the ADA [8-10] recommends a protein intake similar to the general population, based on the recommended dietary allowances (RDA) and dietary reference intakes (Table 2). However, similar to carbohydrates, the definition of protein varies widely in the literature. High-protein diets have been classified as anywhere from $27 \%$ to $68 \%$ of daily energy intake or about 90 to almost $300 \mathrm{~g} /$ day in absolute amounts [89]. When comparing a high-protein (30\% of total calories), low-carbohydrate diet (20\% of total calories) to a moderate-carbohydrate (55\% of total calories), low-protein (15\% of total calories) diet among individuals with Type 2 Diabetes, Gannon and Nuttall [90,91] reported that the high-protein, low-carbohydrate diet reduced fasting plasma glucose, 24-h glucose and HbA1C. The ADA has suggested, in the absence of diabetic kidney disease, higher protein eating patterns ( $30 \%$ of calories) may or may not improve HbAlc; however, they appear to improve one or more CVD risk measures [9]. For individuals with diabetic kidney disease in the presence of either micro- or macroalbuminuria, reducing the amount of protein from normal levels does not appear to alter glycemic measures, CVD risk measures, or the course of renal deterioration [92]. Because protein content changes with carbohydrate and fat, protein changes are typically observed in the context of low-carbohydrate versus moderate- to high-carbohydrate diets, as discussed previously.

Haufe and colleagues [64] randomized 170 overweight and obese individuals to a 6-month dietary intervention with hypocaloric diets $(30 \%$ reduction from usual caloric intake, to a minimum of $1200 \mathrm{cal} /$ day) consisting of low-carbohydrate ( $\leq 90 \mathrm{~g} /$ day $)$, moderate-protein $(0.8 \mathrm{~g} / \mathrm{kg} / \mathrm{day})$ or reduced-fat $(<20 \%)$, moderate-protein $(0.8 \mathrm{~g} / \mathrm{kg} /$ day $)$ intake with the remaining calorie content from carbohydrates. Of 102 subjects that completed the dietary interventions, decreased body weight and improvements in body composition, visceral fat, and intrahepatic lipid content were observed in both groups. There were not significant changes in intrahepatic lipid content, measured by fat spectroscopy, but subjects with high baseline intrahepatic lipids (>5.56\%) lost approximately 7-fold more intrahepatic lipid than those with lower baseline values. These results suggest that in the longer term of 6-months, both low-carbohydrate/high-protein and low-fat diets may be beneficial. However, there is 
insufficient evidence to provide recommendations on protein intake specific for NAFLD, and following the ADA [8-10] and DGAs [49] appear appropriate (Table 2).

\subsection{Micronutrients}

The ADA Recommendations [8,10] do not support a vitamin or mineral intake beyond what is recommended for the general population. Similarly, a recent Cochrane review concluded that there is insufficient evidence for or against the use of supplementation in patients with NAFLD [93]. However, antioxidants may benefit the patient by protecting against oxidative stress.

The AASLD Guidelines [7] recommend a vitamin E intake of 800 international units (IU) per day as first-line therapy for non-diabetic adults with biopsy-proven NASH (Table 2), and benefits have also been reported in children [94,95]. However, limited data exists on the effect of vitamin $\mathrm{E}$ in the general NAFLD population. In a 12-month, double-blind placebo study in a pediatric population $(n=90)$, lifestyle intervention plus supplementation with vitamin E (600 IU/day) and ascorbic acid $(500 \mathrm{mg} /$ day) resulted in significant improvement in liver function and glucose metabolism, but did not significantly differ from the lifestyle intervention only arm [96]. In a subsequent 24-month RCT [97], vitamin E (600 IU/day) plus ascorbic acid (500 IU/day) did not have an effect on increasing the efficacy of lifestyle intervention, but increased physical activity and weight loss were strongly associated with improvements. Vajro et al. [98] conducted a randomized study on vitamin E and hypocaloric dietary intervention and reported that children who adhered only to vitamin $\mathrm{E}$ had complete normalization of transaminase levels, without significant changes in weight status, suggesting independent effects of vitamin E. Two studies comparing the effects of therapeutic intervention for NAFLD supplemented with vitamin E or metformin in children and adolescents [99], and adults [100], did not find evidence of superiority in the vitamin E group. The high-MUFA diet group in the study by Bozetto et al. [73] contained higher amounts of vitamin E [73], questioning the benefits of dietary versus supplemental forms of vitamin $\mathrm{E}$. The use of vitamin $\mathrm{E}$ supplementation is controversial because it has been associated with increased risk of certain types of cancers, bleeding, and hemorrhagic stroke [101], thus, future investigations into its safety and efficacy are warranted.

Reduced intake of vitamin D is common in the Western diet. Targher et al. [102] reported that decreased vitamin D (as 25-hydroxyvitamin D) concentrations in patients with biopsy-proven NAFLD were significantly $(p<0.001)$ and independently associated with increased histological severity of hepatic steatosis and fibrosis. Sprague-Dawley rats fed a high-fat/high-fructose corn syrup diet deficient in vitamin D showed greater hepatic steatosis and up-regulated gene expression of markers of oxidative stress and inflammation, compared to the group with sufficient vitamin D [103]. However, there is insufficient evidence to recommend that patients with NAFLD consume more than the RDA for vitamin D (600 IU/day for 19-70 year old males and females, and $800 \mathrm{IU} /$ day for adults over 70 years). Future investigations should examine the biological role of these vitamins in NAFLD pathogenesis, and whether increasing their amount through diet or supplementation to that beyond the RDA has therapeutic effects. 


\subsection{Summary of Medical Nutrition Therapy}

There are limited randomized intervention studies to generate evidence-based dietary recommendations for NAFLD. Carbohydrate source, fiber, and glycemic index are important to consider in meal planning for NAFLD patients. The ADA recommends consuming a diet rich in carbohydrate from fruits, vegetables, whole grains, and legumes for good health and improved blood glucose control. A moderate-carbohydrate diet $(40 \%-65 \%$ of energy) is consistent with the ADA recommendations $[8,10]$ and DGAs (Table 2) [49].

Patients with NAFLD may benefit from a moderate- to low-carbohydrate $(40 \%-45 \%$ of total calories) diet, coupled with increased dietary MUFA and n-3 PUFAs. This macronutrient distribution is typical of Mediterranean-style diets. As highlighted by McCarthy and Rinella [47], avoiding HFCS may be an important recommendation for patients with NAFLD. Diets rich in $n-3$ PUFAs and MUFAs may confer additional anti-inflammatory and cardiovascular benefits, particularly when they replace SFAs [47]. Either low-carbohydrate or low-fat, calorie-restricted diets may be effective in the short term (up to 1-year), and nutrition counseling should be individually based. At this time, there is insufficient evidence for or against the use of nutritional supplements in the NAFLD population, with or without insulin resistance, but patients with NASH may benefit from antioxidant supplementation with vitamin E (800 IU/day).

\section{Conclusions}

This review highlights the growing prevalence of NAFLD. NAFLD is regarded as the hepatic manifestation of the metabolic syndrome and shares common comorbidities with insulin resistance and CVD. It is important for clinicians to recognize this patient population and deliver effective therapeutic lifestyle interventions. In addition, patients may benefit from referral to MNT to optimize dietary intake and promote behavioral changes [104]. The ADA provides evidence-based nutrition recommendations [8-10] for preventing and managing type 2 diabetes, insulin resistance, and reducing CVD risk factors. We propose these guidelines are complementary to existing guidelines for NAFLD [7], and can serve as a facilitator in the development of evidenced-based lifestyle intervention recommendations. Future research is needed to evaluate low-carbohydrate/high MUFA and low-fat/low-GI diets for NAFLD. Challenges in evaluating the evidence regarding the effects of foods and macronutrients on metabolic parameters in NAFLD management include variability in study methodology (e.g., measurement of dietary intake, small study samples for intervention trials, confounding by weight loss). Additionally, there is abundant literature examining the effects of lifestyle intervention on metabolic parameters such as lipids, glycemic control, and insulin resistance, but few have measured liver-related outcomes. If future studies in the diabetic population consider including NAFLD outcomes (e.g., serum AST/ALT, imaging, biopsy) when feasible, this would greatly add to the literature and facilitate the formation of evidence-based guidelines. It is likely that many patients with diabetes have NAFLD and therefore should follow dietary and lifestyle recommendations provided by the ADA [8-10] to achieve and maintain health. The ADA recommendations [8-10] may also benefit non-diabetic NAFLD patients by promoting weight management and preventing the onset of additional metabolic complications. 


\section{Conflicts of Interest}

The authors declare no conflict of interest.

\section{References}

1. Bellentani, S.; Scaglioni, F.; Marino, M.; Bedogni, G. Epidemiology of non-alcoholic fatty liver disease. Dig. Dis. 2010, 28, 155-161.

2. Vernon, G.; Baranova, A.; Younossi, Z.M. Systematic review: The epidemiology and natural history of non-alcoholic fatty liver disease and non-alcoholic steatohepatitis in adults. Aliment. Pharmacol. Ther. 2011, 34, 274-285.

3. Rinella, M.E. Will the increased prevalence of nonalcoholic steatohepatitis (NASH) in the age of better hepatitis $C$ virus therapy make nash the deadlier disease? Hepatology 2011, 54, 1118-1120.

4. Targher, G.; Bertolini, L.; Padovani, R.; Rodella, S.; Tessari, R.; Zenari, L.; Day, C.; Arcaro, G. Prevalence of nonalcoholic fatty liver disease and its association with cardiovascular disease among tyep 2 diabetic patients. Diabetes Care 2007, 30, 1212-1218.

5. Leite, N.C.; Salles, G.F.; Araujo, A.L.; Villela-Nogueira, C.A.; Cardoso, C.R. Prevalence and associated factors of non-alcoholic fatty liver disease in patients with type-2 diabetes mellitus. Liver Int. 2009, 29, 113-119.

6. Targher, G.; Day, C.P.; Bonora, E. Risk of cardiovascular disease in patients with nonalcoholic fatty liver disease. N. Engl. J. Med. 2010, 363, 1341-1350.

7. Chalasani, N.; Younossi, Z.; Lavine, J.E.; Diehl, A.M.; Brunt, E.M.; Cusi, K.; Charlton, M.; Sanyal, A.J. The diagnosis and management of non-alcoholic fatty liver disease: Practice guideline by the american association for the study of liver diseases, american college of gastroenterology, and the american gastroenterological association. Am. J. Gastroenterol. 2012, 55, 2005-2023.

8. Bantle, J.P.; Wylie-Rosett, J.; Albright, A.L.; Apovian, C.M.; Clark, N.G.; Franz, M.J.; Hoogwerf, B.J.; Lichtenstein, A.H.; Mayer-Davis, E.; Mooradian, A.D.; et al. Nutrition recommendations and interventions for diabetes: A position statement of the american diabetes association. Diabetes Care 2008, 31, S61-S78.

9. Wheeler, M.L.; Dunbar, S.A.; Jaacks, L.M.; Karmally, W.; Mayer-Davis, E.J.; Wylie-Rosett, J.; Yancy, W.S., Jr. Macronutrients, food groups, and eating patterns in the management of diabetes: A systematic review of the literature, 2010. Diabetes Care 2012, 35, 434-445.

10. American Diabetes Association. Standards of medical care in diabetes-2013. Diabetes Care 2013, 36, S11-S66.

11. Ratziu, V.; Bellentani, S.; Cortez-Pinto, H.; Day, C.; Marchesini, G. A position statement on nafld/nash based on the easl 2009 special conference. J. Hepatol. 2010, 53, 372-384.

12. Sanyal, A.J.; Brunt, E.M.; Kleiner, D.E.; Kowdley, K.V.; Chalasani, N.; Lavine, J.E.; Ratziu, V.; McCullough, A. Endpoints and clinical trial design for nonalcoholic steatohepatitis. Hepatology 2011, 54, 344-353.

13. Kneeman, J.M.; Misdraji, J.; Corey, K.E. Secondary causes of nonalcoholic fatty liver disease. Ther. Adv. Gastroenterol. 2012, 5, 199-207. 
14. Global Status Report on Noncommunicable Diseases 2010; World Health Organization, Ed.; World Health Organization: Geneva, Switzerland, 2011. Available online: http://www.who.int/nmh/publications/ncd_report2010/en/ (accessed on 7 August 2013).

15. Nguyen, D.M.; El-Serag, H.B. The epidemiology of obesity. Gastroenterol. Clin. N. Am. 2010, 39, 1-7.

16. Medina-Santillan, R.; Lopez-Velazquez, J.A.; Chavez-Tapia, N.; Torres-Villalobos, G.; Uribe, M.; Mendez-Sanchez, N. Hepatic manifestations of metabolic syndrome. Diabetes Metab. Res. Rev. 2013, doi:10.1002/dmrr.2410.

17. Gholam, P.M.; Flancbaum, L.; Machan, J.T.; Charney, D.A.; Kotler, D.P. Nonalcoholic fatty liver disease in severely obese subjects. Am. J. Gastroenterol. 2007, 102, 399-408.

18. Wong, V.W.; Wong, G.L.; Choi, P.C.; Chan, A.W.; Li, M.K.; Chan, H.Y.; Chim, A.M.; Yu, J.; Sung, J.J.; Chan, H.L. Disease progression of non-alcoholic fatty liver disease: A prospective study with paired liver biopsies at 3 years. Gut 2010, 59, 969-974.

19. Farrell, G.C.; van Rooyen, D.; Gan, L.; Chitturi, S. Nash is an inflammatory disorder: Pathogenic, prognostic and therapeutic implications. Gut Liver 2012, 6, 149-171.

20. Huang, H.L.; Lin, W.Y.; Lee, L.T.; Wang, H.H.; Lee, W.J.; Huang, K.C. Metabolic syndrome is related to nonalcoholic steatohepatitis in severely obese subjects. Obes. Surg. 2007, 17, $1457-1463$.

21. Kang, H.; Greenson, J.K.; Omo, J.T.; Chao, C.; Peterman, D.; Anderson, L.; Foess-Wood, L.; Sherbondy, M.A.; Conjeevaram, H.S. Metabolic syndrome is associated with greater histologic severity, higher carbohydrate, and lower fat diet in patients with nafld. Am. J. Gastroenterol. 2006, 101, 2247-2253.

22. Ogden, C.L.; Carroll, M.D.; Kit, B.K.; Flegal, K.M. Prevalence of obesity and trends in body mass index among U.S. children and adolescents, 1999-2010. JAMA 2012, 307, 483-490.

23. Vajro, P.; Lenta, S.; Socha, P.; Dhawan, A.; McKiernan, P.; Baumann, U.; Durmaz, O.; Lacaille, F.; McLin, V.; Nobili, V. Diagnosis of nonalcoholic fatty liver disease in children and adolescents: Position paper of the espghan hepatology committee. J. Pediatr. Gastroenterol. Nutr. 2012, 54, 700-713.

24. Stepanova, M.; Rafiq, N.; Younossi, Z.M. Components of metabolic syndrome are independent predictors of mortality in patients with chronic liver disease: A population-based study. Gut 2010, 59, 1410-1415.

25. Targher, G.; Bertolini, L.; Padovani, R.; Rodella, S.; Zoppini, G.; Pichiri, I.; Sorgato, C.; Zenari, L.; Bonora, E. Prevalence of non-alcoholic fatty liver disease and its association with cardiovascular disease in patients with type 1 diabetes. J. Hepatol. 2010, 53, 713-718.

26. Bremer, A.A.; Mietus-Snyder, M.; Lustig, R.H. Toward a unifying hypothesis of metabolic syndrome. Pediatrics 2012, 129, 557-570.

27. Grundy, S.M.; Cleeman, J.I.; Daniels, S.R.; Donato, K.A.; Eckel, R.H.; Franklin, B.A.; Gordon, D.J.; Krauss, R.M.; Savage, P.J.; Smith, S.C., Jr.; et al. Diagnosis and management of the metabolic syndrome: An american heart association/national heart, lung, and blood institute scientific statement. Circulation 2005, 112, 2735-2752. 
28. Expert Panel on Detection, Evaluation Treatment of High Blood Cholesterol in Adults. Executive summary of the third report of the national cholesterol education program (NCEP) expert panel on detection, evaluation, and treatment of high blood cholesterol in adults (adult treatment panel III). JAMA 2001, 285, 2486-2497.

29. Browning, J.D.; Szczepaniak, L.S.; Dobbins, R.; Nuremberg, P.; Horton, J.D.; Cohen, J.C.; Grundy, S.M.; Hobbs, H.H. Prevalence of hepatic steatosis in an urban population in the united states: Impact of ethnicity. Hepatology 2004, 40, 1387-1395.

30. Hu, X.; Huang, Y.; Bao, Z.; Wang, Y.; Shi, D.; Liu, F.; Gao, Z.; Yu, X. Prevalence and factors associated with nonalcoholic fatty liver disease in shanghai work-units. BMC Gastroenterol. 2012, 12, 123, doi:10.1186/1471-230X-12-123.

31. Weston, S.R.; Leyden, W.; Murphy, R.; Bass, N.M.; Bell, B.P.; Manos, M.M.; Terrault, N.A. Racial and ethnic distribution of nonalcoholic fatty liver in persons with newly diagnosed chronic liver disease. Hepatology 2005, 41, 372-379.

32. Smith, B.W.; Adams, L.A. Nonalcoholic fatty liver disease and diabetes mellitus: Pathogenesis and treatment. Nat. Rev. Endocrinol. 2011, 7, 456-465.

33. Johnson, A.M.; Olefsky, J.M. The origins and drivers of insulin resistance. Cell 2013, 152, 673-684.

34. Day, C.P.; James, O.F. Steatohepatitis: A tale of two "hits"? Gastroenterology 1998, 114, 842-845.

35. Novo, E.; Parola, M. Redox mechanisms in hepatic chronic wound healing and fibrogenesis. Fibrogenesis Tissue Repair 2008, 1, 5, doi:10.1186/1755-1536-1-5.

36. Gaggini, M.; Morelli, M.; Buzzigoli, E.; DeFronzo, R.A.; Bugianesi, E.; Gastaldelli, A. Non-alcoholic fatty liver disease (NAFLD) and its connection with insulin resistance, dyslipidemia, atherosclerosis and coronary heart disease. Nutrients 2013, 5, 1544-1560.

37. Araya, J.; Rodrigo, R.; Videla, L.A.; Thielemann, L.; Orellana, M.; Pettinelli, P.; Poniachik, J. Increase in long-chain polyunsaturated fatty acid $n-6 / n-3$ ratio in relation to hepatic steatosis in patients with non-alcoholic fatty liver disease. Clin. Sci. (Lond.) 2004, 106, 635-643.

38. Zuniga, J.; Cancino, M.; Medina, F.; Varela, P.; Vargas, R.; Tapia, G.; Videla, L.A.; Fernandez, V. $N-3$ pufa supplementation triggers ppar- $\alpha$ activation and ppar- $\alpha /$ nf-kappab interaction: Anti-inflammatory implications in liver ischemia-reperfusion injury. PLoS One 2011, 6, e28502.

39. Pettinelli, P.; Del Pozo, T.; Araya, J.; Rodrigo, R.; Araya, A.V.; Smok, G.; Csendes, A.; Gutierrez, L.; Rojas, J.; Korn, O.; et al. Enhancement in liver srebp-1c/ppar- $\alpha$ ratio and steatosis in obese patients: Correlations with insulin resistance and $n$-3 long-chain polyunsaturated fatty acid depletion. Biochim. Biophys. Acta 2009, 1792, 1080-1086.

40. Xu, W.; Shao, L.; Zhou, C.; Wang, H.; Guo, J. Upregulation of nrf2 expression in non-alcoholic fatty liver and steatohepatitis. Hepatogastroenterology 2011, 58, 2077-2080.

41. Ibdah, J.A.; Perlegas, P.; Zhao, Y.; Angdisen, J.; Borgerink, H.; Shadoan, M.K.; Wagner, J.D.; Matern, D.; Rinaldo, P.; Cline, J.M. Mice heterozygous for a defect in mitochondrial trifunctional protein develop hepatic steatosis and insulin resistance. Gastroenterology 2005, 128, $1381-1390$. 
42. Machado, M.V.; Coutinho, J.; Carepa, F.; Costa, A.; Proenca, H.; Cortez-Pinto, H. How adiponectin, leptin, and ghrelin orchestrate together and correlate with the severity of nonalcoholic fatty liver disease. Eur. J. Gastroenterol. Hepatol. 2012, 24, 1166-1172.

43. Al-Busafi, S.A.; Bhat, M.; Wong, P.; Ghali, P.; Deschenes, M. Antioxidant therapy in nonalcoholic steatohepatitis. Hepat. Res. Treat. 2012, 2012, 947575, doi:10.1155/2012/947575.

44. Daly, M.E.; Paisey, R.; Paisey, R.; Millward, B.A.; Eccles, C.; Williams, K.; Hammersley, S.; MacLeod, K.M.; Gale, T.J. Short-term effects of severe dietary carbohydrate-restriction advice in type 2 diabetes-A randomized controlled trial. Diabet. Med. 2006, 23, 15-20.

45. Suzuki, A.; Lindor, K.; St Saver, J.; Lymp, J.; Mendes, F.; Muto, A.; Okada, T.; Angulo, P. Effect of changes on body weight and lifestyle in nonalcoholic fatty liver disease. J. Hepatol. 2005, 43, 1060-1066.

46. Lazo, M.; Solga, S.F.; Horska, A.; Bonekamp, S.; Diehl, A.M.; Brancati, F.L.; Wagenknecht, L.E.; Pi-Sunyer, F.X.; Kahn, S.E.; Clark, J.M.; et al. Effect of a 12-month intensive lifestyle intervention on hepatic steatosis in adults with type 2 diabetes. Diabetes Care 2010, 33, 2156-2163.

47. McCarthy, E.M.; Rinella, M.E. The role of diet and nutrient composition in nonalcoholic fatty liver disease. J. Acad. Nutr. Diet. 2012, 112, 401-409.

48. American Dietetic Association. Nutrition Diagnosis: A Critical Step in the Nutrition Care Process; American Dietetic Association: Chicago, IL, USA, 2006.

49. U.S. Department of Agriculture; U.S. Department of Health and Human Services. Dietary Guidelines for Americans, 2010; U.S. Government Printing Office: Washington, DC, USA, 2010.

50. National Heart, Lung, and Blood Institute; National Institute of Diabetes and Digestive and Kidney Diseases. Clinical Guidelines on the Identification, Evaluation, and Treatment of Overweight and Obesity in Adults; The Evidence Report; National Institutes of Health: Bethesda, MD, USA, 1998. Available online: http://www.nhlbi.nih.gov/guidelines/obesity/ob_gdlns.pdf (accessed on 12 August 2013).

51. Esposito, K.; Maiorino, M.I.; Ciotola, M.; Di Palo, C.; Scognamiglio, P.; Gicchino, M.; Petrizzo, M.; Saccomanno, F.; Beneduce, F.; Ceriello, A.; et al. Effects of a mediterranean-style diet on the need for antihyperglycemic drug therapy in patients with newly diagnosed type 2 diabetes: A randomized trial. Ann. Intern. Med. 2009, 151, 306-314.

52. Sargrad, K.R.; Homko, C.; Mozzoli, M.; Boden, G. Effect of high protein vs high carbohydrate intake on insulin sensitivity, body weight, hemoglobin alc, and blood pressure in patients with type 2 diabetes mellitus. J. Am. Diet. Assoc. 2005, 105, 573-580.

53. Davis, N.J.; Tomuta, N.; Schechter, C.; Isasi, C.R.; Segal-Isaacson, C.J.; Stein, D.; Zonszein, J.; Wylie-Rosett, J. Comparative study of the effects of a 1-year dietary intervention of a low-carbohydrate diet versus a low-fat diet on weight and glycemic control in type 2 diabetes. Diabetes Care 2009, 32, 1147-1152.

54. Castaneda-Gonzalez, L.M.; Bacardi Gascon, M.; Jimenez Cruz, A. Effects of low carbohydrate diets on weight and glycemic control among type 2 diabetes individuals: A systemic review of rct greater than 12 weeks. Nutr. Hosp. 2011, 26, 1270-1276. 
55. Zelber-Sagi, S.; Nitzan-Kaluski, D.; Goldsmith, R.; Webb, M.; Blendis, L.; Halpern, Z.; Oren, R. Long term nutritional intake and the risk for non-alcoholic fatty liver disease (NAFLD): A population based study. J. Hepatol. 2007, 47, 711-717.

56. Oddy, W.H.; Herbison, C.E.; Jacoby, P.; Ambrosini, G.L.; O’Sullivan, T.A.; Ayonrinde, O.T.; Olynyk, J.K.; Black, L.J.; Beilin, L.J.; Mori, T.A.; et al. The western dietary pattern is prospectively associated with nonalcoholic fatty liver disease in adolescence. Am. J. Gastroenterol. 2013, 108, 778-785.

57. Esfahani, A.; Wong, J.M.; Mirrahimi, A.; Srichaikul, K.; Jenkins, D.J.; Kendall, C.W. The glycemic index: Physiological significance. J. Am. Coll. Nutr. 2009, 28, 439S-445S.

58. Zivkovic, A.M.; German, J.B.; Sanyal, A.J. Comparative review of diets for the metabolic syndrome: Implications for nonalcoholic fatty liver disease. Am. J. Clin. Nutr. 2007, 86, 285-300.

59. Thomas, D.; Elliott, E.J. Low glycaemic index, or low glycaemic load, diets for diabetes mellitus. Cochrane Database Syst. Rev. 2009, CD006296, doi:10.1002/14651858.CD006296.pub2.

60. Wylie-Rosett, J.; Segal-Isaacson, C.J.; Segal-Isaacson, A. Carbohydrates and increases in obesity: Does the type of carbohydrate make a difference? Obes. Res. 2004, 12, 124S-129S.

61. Valtuena, S.; Pellegrini, N.; Ardigo, D.; del Rio, D.; Numeroso, F.; Scazzina, F.; Monti, L.; Zavaroni, I.; Brighenti, F. Dietary glycemic index and liver steatosis. Am. J. Clin. Nutr. 2006, 84, $136-142$.

62. Wylie-Rosett, J.; Aebersold, K.; Conlon, B.; Isasi, C.R.; Ostrovsky, N.W. Health effects of low-carbohydrate diets: Where should new research go? Curr. Diabetes Rep. 2012, 13, 271-278.

63. Ryan, M.C.; Abbasi, F.; Lamendola, C.; Carter, S.; McLaughlin, T.L. Serum alanine aminotransferase levels decrease further with carbohydrate than fat restriction in insulin-resistant adults. Diabetes Care 2007, 30, 1075-1080.

64. Haufe, S.; Engeli, S.; Kast, P.; Bohnke, J.; Utz, W.; Haas, V.; Hermsdorf, M.; Mahler, A.; Wiesner, S.; Birkenfeld, A.L.; et al. Randomized comparison of reduced fat and reduced carbohydrate hypocaloric diets on intrahepatic fat in overweight and obese human subjects. Hepatology 2011, 53, 1504-1514.

65. Roberts, R.; Bickerton, A.S.; Fielding, B.A.; Blaak, E.E.; Wagenmakers, A.J.; Chong, M.F.; Gilbert, M.; Karpe, F.; Frayn, K.N. Reduced oxidation of dietary fat after a short term high-carbohydrate diet. Am. J. Clin. Nutr. 2008, 87, 824-831.

66. Culling, K.S.; Neil, H.A.; Gilbert, M.; Frayn, K.N. Effects of short-term low- and high-carbohydrate diets on postprandial metabolism in non-diabetic and diabetic subjects. Nutr. Metab. Cardiovasc. Dis. 2009, 19, 345-351.

67. Ouyang, X.; Cirillo, P.; Sautin, Y.; McCall, S.; Bruchette, J.L.; Diehl, A.M.; Johnson, R.J.; Abdelmalek, M.F. Fructose consumption as a risk factor for non-alcoholic fatty liver disease. J. Hepatol. 2008, 48, 993-999.

68. Montonen, J.; Jarvinen, R.; Knekt, P.; Heliovaara, M.; Reunanen, A. Consumption of sweetened beverages and intakes of fructose and glucose predict type 2 diabetes occurrence. J. Nutr. 2007, 137, 1447-1454. 
69. Jin, R.; Le, N.A.; Liu, S.; Farkas Epperson, M.; Ziegler, T.R.; Welsh, J.A.; Jones, D.P.; McClain, C.J.; Vos, M.B. Children with nafld are more sensitive to the adverse metabolic effects of fructose beverages than children without NAFLD. J. Clin. Endocrinol. Metab. 2012, 97, E1088-E1098.

70. Videla, L.A.; Rodrigo, R.; Araya, J.; Poniachik, J. Insulin resistance and oxidative stress interdependency in non-alcoholic fatty liver disease. Trends Mol. Med. 2006, 12, 555-558.

71. Assy, N.; Nassar, F.; Nasser, G.; Grosovski, M. Olive oil consumption and non-alcoholic fatty liver disease. World J. Gastroenterol. 2009, 15, 1809-1815.

72. American Heart Association Nutrition Committee; Lichtenstein, A.H.; Appel, L.J.; Brands, M.; Carnethon, M.; Daniels, S.; Franch, H.A.; Franklin, B.; Kris-Etherton, P.; Harris, W.S.; et al. Diet and lifestyle recommendations revision 2006: A scientific statement from the american heart association nutrition committee. Circulation 2006, 114, 82-96.

73. Bozzetto, L.; Prinster, A.; Annuzzi, G.; Costagliola, L.; Mangione, A.; Vitelli, A.; Mazzarella, R.; Longobardo, M.; Mancini, M.; Vigorito, C.; et al. Liver fat is reduced by an isoenergetic mufa diet in a controlled randomized study in type 2 diabetic patients. Diabetes Care 2012, 35, 1429-1435.

74. Westerbacka, J.; Lammi, K.; Hakkinen, A.M.; Rissanen, A.; Salminen, I.; Aro, A.; Yki-Jarvinen, H. Dietary fat content modifies liver fat in overweight nondiabetic subjects. J. Clin. Endocrinol. Metab. 2005, 90, 2804-2809.

75. Rivellese, A.A.; Giacco, R.; Annuzzi, G.; De Natale, C.; Patti, L.; Di Marino, L.; Minerva, V.; Costabile, G.; Santangelo, C.; Masella, R.; et al. Effects of monounsaturated vs. Saturated fat on postprandial lipemia and adipose tissue lipases in type 2 diabetes. Clin. Nutr. 2008, 27, 133-141.

76. Estruch, R.; Ros, E.; Salas-Salvado, J.; Covas, M.I.; Corella, D.; Aros, F.; Gomez-Gracia, E.; Ruiz-Gutierrez, V.; Fiol, M.; Lapetra, J.; et al. Primary prevention of cardiovascular disease with a mediterranean diet. N. Engl. J. Med. 2013, 368, 1279-1290.

77. Perez-Guisado, J.; Munoz-Serrano, A. The effect of the spanish ketogenic mediterranean diet on nonalcoholic fatty liver disease: A pilot study. J. Med. Food 2011, 14, 677-680.

78. Perez-Guisado, J.; Munoz-Serrano, A. A pilot study of the spanish ketogenic mediterranean diet: An effective therapy for the metabolic syndrome. J. Med. Food 2011, 14, 681-687.

79. Dunn, W.; Xu, R.; Schwimmer, J.B. Modest wine drinking and decreased prevalence of suspected nonalcoholic fatty liver disease. Hepatology 2008, 47, 1947-1954.

80. Mostad, I.L.; Bjerve, K.S.; Bjorgaas, M.R.; Lydersen, S.; Grill, V. Effects of $n-3$ fatty acids in subjects with type 2 diabetes: Reduction of insulin sensitivity and time-dependent alteration from carbohydrate to fat oxidation. Am. J. Clin. Nutr. 2006, 84, 540-550.

81. Pooya, S.; Jalali, M.D.; Jazayery, A.D.; Saedisomeolia, A.; Eshraghian, M.R.; Toorang, F. The efficacy of omega-3 fatty acid supplementation on plasma homocysteine and malondialdehyde levels of type 2 diabetic patients. Nutr. Metab. Cardiovasc. Dis. 2010, 20, 326-331.

82. Nobili, V.; Bedogni, G.; Alisi, A.; Pietrobattista, A.; Rise, P.; Galli, C.; Agostoni, C. Docosahexaenoic acid supplementation decreases liver fat content in children with non-alcoholic fatty liver disease: Double-blind randomised controlled clinical trial. Arch. Dis. Child. 2011, 96, $350-353$. 
83. Zhu, F.S.; Liu, S.; Chen, X.M.; Huang, Z.G.; Zhang, D.W. Effects of $n$-3 polyunsaturated fatty acids from seal oils on nonalcoholic fatty liver disease associated with hyperlipidemia. World $J$. Gastroenterol. 2008, 14, 6395-6400.

84. Spadaro, L.; Magliocco, O.; Spampinato, D.; Piro, S.; Oliveri, C.; Alagona, C.; Papa, G.; Rabuazzo, A.M.; Purrello, F. Effects of $n-3$ polyunsaturated fatty acids in subjects with nonalcoholic fatty liver disease. Dig. Liver Dis. 2008, 40, 194-199.

85. Capanni, M.; Calella, F.; Biagini, M.R.; Genise, S.; Raimondi, L.; Bedogni, G.; Svegliati-Baroni, G.; Sofi, F.; Milani, S.; Abbate, R.; et al. Prolonged $n-3$ polyunsaturated fatty acid supplementation ameliorates hepatic steatosis in patients with non-alcoholic fatty liver disease: A pilot study. Aliment. Pharmacol. Ther. 2006, 23, 1143-1151.

86. Sofi, F.; Giangrandi, I.; Cesari, F.; Corsani, I.; Abbate, R.; Gensini, G.F.; Casini, A. Effects of a 1-year dietary intervention with $n-3$ polyunsaturated fatty acid-enriched olive oil on non-alcoholic fatty liver disease patients: A preliminary study. Int. J. Food Sci. Nutr. 2010, 61, 792-802.

87. Hatzitolios, A.; Savopoulos, C.; Lazaraki, G.; Sidiropoulos, I.; Haritanti, P.; Lefkopoulos, A.; Karagiannopoulou, G.; Tzioufa, V.; Dimitrios, K. Efficacy of omega-3 fatty acids, atorvastatin and orlistat in non-alcoholic fatty liver disease with dyslipidemia. Indian J. Gastroenterol. 2004, 23, 131-134.

88. Tanaka, N.; Sano, K.; Horiuchi, A.; Tanaka, E.; Kiyosawa, K.; Aoyama, T. Highly purified eicosapentaenoic acid treatment improves nonalcoholic steatohepatitis. J. Clin. Gastroenterol. 2008, 42, 413-418.

89. Paddon-Jones, D.; Westman, E.; Mattes, R.D.; Wolfe, R.R.; Astrup, A.; Westerterp-Plantenga, M. Protein, weight management, and satiety. Am. J. Clin. Nutr. 2008, 87, 1558S-1561S.

90. Gannon, M.C.; Nuttall, F.Q. Effect of a high-protein, low-carbohydrate diet on blood glucose control in people with type 2 diabetes. Diabetes 2004, 53, 2375-2382.

91. Gannon, M.C.; Nuttall, F.Q.; Saeed, A.; Jordan, K.; Hoover, H. An increase in dietary protein improves the blood glucose response in persons with type 2 diabetes. Am. J. Clin. Nutr. 2003, 78, 734-741.

92. Gross, J.L.; Zelmanovitz, T.; Moulin, C.C.; De Mello, V.; Perassolo, M.; Leitao, C.; Hoefel, A.; Paggi, A.; Azevedo, M.J. Effect of a chicken-based diet on renal function and lipid profile in patients with type 2 diabetes: A randomized crossover trial. Diabetes Care 2002, 25, 645-651.

93. Lirussi, F.; Azzalini, L.; Orando, S.; Orlando, R.; Angelico, F. Antioxidant supplements for non-alcoholic fatty liver disease and/or steatohepatitis. Cochrane Database Syst. Rev. 2007, CD004996, doi:10.1002/14651858.CD004996.pub3.

94. Lavine, J.E. Vitamin E treatment of nonalcoholic steatohepatitis in children: A pilot study. J. Pediatr. 2000, 136, 734-738.

95. Pacana, T.; Sanyal, A.J. Vitamin E and nonalcoholic fatty liver disease. Curr. Opin. Clin. Nutr. Metab. Care 2012, 15, 641-648.

96. Nobili, V.; Manco, M.; Devito, R.; Ciampalini, P.; Piemonte, F.; Marcellini, M. Effect of vitamin $\mathrm{E}$ on aminotransferase levels and insulin resistance in children with non-alcoholic fatty liver disease. Aliment. Pharmacol. Ther. 2006, 24, 1553-1561. 
97. Nobili, V.; Manco, M.; Devito, R.; Di Ciommo, V.; Comparcola, D.; Sartorelli, M.R.; Piemonte, F.; Marcellini, M.; Angulo, P. Lifestyle intervention and antioxidant therapy in children with nonalcoholic fatty liver disease: A randomized, controlled trial. Hepatology 2008, 48, 119-128.

98. Vajro, P.; Mandato, C.; Franzese, A.; Ciccimarra, E.; Lucariello, S.; Savoia, M.; Capuano, G.; Migliaro, F. Vitamin E treatment in pediatric obesity-related liver disease: A randomized study. J. Pediatr. Gastroenterol. Nutr. 2004, 38, 48-55.

99. Lavine, J.E.; Schwimmer, J.B.; van Natta, M.L.; Molleston, J.P.; Murray, K.F.; Rosenthal, P.; Abrams, S.H.; Scheimann, A.O.; Sanyal, A.J.; Chalasani, N.; et al. Effect of vitamin E or metformin for treatment of nonalcoholic fatty liver disease in children and adolescents: The tonic randomized controlled trial. JAMA 2011, 305, 1659-1668.

100. Bugianesi, E.; Gentilcore, E.; Manini, R.; Natale, S.; Vanni, E.; Villanova, N.; David, E.; Rizzetto, M.; Marchesini, G. A randomized controlled trial of metformin versus vitamin $\mathrm{E}$ or prescriptive diet in nonalcoholic fatty liver disease. Am. J. Gastroenterol. 2005, 100, 1082-1090.

101. National Instittues of Health; Office of Dietary Supplements. Dietary Supplement Fact Sheet: Vitamin E. Available online: http://ods.od.nih.gov/factsheets/VitaminE-QuickFacts/ (accessed on 6 May 2013).

102. Targher, G.; Bertolini, L.; Scala, L.; Cigolini, M.; Zenari, L.; Falezza, G.; Arcaro, G. Associations between serum 25-hydroxyvitamin D3 concentrations and liver histology in patients with non-alcoholic fatty liver disease. Nutr. Metab. Cardiovasc. Dis. 2007, 17, 517-524.

103. Roth, C.L.; Elfers, C.T.; Figlewicz, D.P.; Melhorn, S.J.; Morton, G.J.; Hoofnagle, A.; Yeh, M.M.; Nelson, J.E.; Kowdley, K.V. Vitamin D deficiency in obese rats exacerbates nonalcoholic fatty liver disease and increases hepatic resistin and toll-like receptor activation. Hepatology 2012, 55, 1103-1111.

104. Spahn, J.M.; Reeves, R.S.; Keim, K.S.; Laquatra, I.; Kellogg, M.; Jortberg, B.; Clark, N.A. State of the evidence regarding behavior change theories and strategies in nutrition counseling to facilitate health and food behavior change. J. Am. Diet. Assoc. 2010, 110, 879-891.

(C) 2013 by the authors; licensee MDPI, Basel, Switzerland. This article is an open access article distributed under the terms and conditions of the Creative Commons Attribution license (http://creativecommons.org/licenses/by/3.0/). 